\title{
Evaluation of Phytochemicals and In Vitro Anticancer Activity of Eupatorium Triplinerve
}

\author{
Suja G. ${ }^{1}$, Vinoth Kumar T. ${ }^{2 *}$, Suganya P. ${ }^{3}$ \\ ${ }^{1,2,3}$ Dept. of Biotechnology, School of Biological Sciences, CMS College of Science and Commerce, Coimbatore, Tamil Nadu, \\ India
}

*Corresponding author: vinothbiochem@gmail.com, +91-9486094219

Available online at: www.isroset.org

Received: 27/Sept/2019, Accepted: 15/Oct/2019, Online: 31/Oct/2019

\begin{abstract}
The present study attempts to evaluate the phytochemical activity and in vitro anticancer activity of Eupatorium triplinerve methanol extract against lung cancer cell line A-549 and normal cell line Vero. The compound was analyzed for the presence of various phytoconstituents and screened for its cytotoxicity at five different concentrations by MTT assay. The phytochemical profile exhibited the presence of alkaloids, phenolics, flavonoids and steroids. The study documented that the percentage of cell viability has been reduced with the increased concentration, as evidenced by cell death. Eupatorium triplinerve extract shows potential cytotoxic activity with $\mathrm{CTC}_{50}$ of $450 \mu \mathrm{g} / \mathrm{ml}$ and $110 \mu \mathrm{g} / \mathrm{ml}$ against A-549 and Vero cell line respectively. The result obtained was comparably potent, the crude extract showed moderate activity against cancer cells and it was less toxic to the normal cells. In future, research need to be explored in the purification of this extract and identification of lead compound which could be used as a therapeutic tool against lung cancer.
\end{abstract}

Keywords: Anticancer, In vitro, Plant extract, Eupatorium triplinerve, Cytotoxicity, MTT assay.

\section{INTRODUCTION}

Cancer is still a major threat among the raising human population, despite the development of advancements in medical science and the modern therapeutic techniques. Cancer has been developed as a major global problem matching its effects in the industrializing nations due to their changes in lifestyle and average increase in life span [1]. This may affect any social class, any race or any age group, even the foetus.

Cancer is caused by uncontrolled proliferation of cell which is mainly due to the failure in checkpoint machinery that neglects to identify the flaw during cell division. The cancer cells do not sustain apoptosis meanwhile it causes damage to healthy cells by metastasis. So, the complete cell cycle gets affected and the whole system gets disintegrated [2].

Presently chemotherapy is one of the commonly used treatments among various types of therapies. But the usage of this treatment is refused continuously among the society because of its nature of causing side effects. The way of damaging the normal cells along with the cancerous cells turns the whole world towards the natural resources like plants for the purpose of non-toxic remedies [3].

Plants are the resources of many chemical substances which are classified as primary and secondary metabolites, where the secondary compound have no direct role in the growth and development of plants rather than act as a natural drug for various diseases. The active compound present in the medicinal plants are act as the biological agents like antiinflammatory, anticancer, contraceptive and has different effects on hematopoietic cells, [4] lipids [5] and cardiovascular systems [6].

The plant Eupatorium triplinerve is selected for the isolation of active compound for anticancer activity. It is an ornamental erect perennial herb with aromatic leaves found in and around the districts of Coimbatore and The Nilgiris of Tamil Nadu. Traditionally the whole plant is used in the diseases of liver, spleen, abdominal complaints and tumours. The investigation of this study is based on their use in traditional system of medicine.

The present study deals to evaluate the potency of methanol crude extract from Eupatorium triplinerve against the lung cancer cell line and further suggested for the isolation and identification of potential anticancer drug.

\section{MATERIALS AND METHODS}

\section{Cell lines and culture conditions}

In this study two cell lines were used viz., Lung cancer cell line (A 549) and the normal fibroblast cells (Vero). The cell 
line was procured from National Centre for Cell Sciences (NCCS), Pune.

The cell lines were grown in Dulbecco's Modified Eagle Medium (DMEM) supplemented with $2 \mathrm{mM}$ glutamine, 1.5 $\mathrm{mM}$ sodium pyruvate, $0.2 \mathrm{mM}$ essential amino acids, $2 \mathrm{~g} / \mathrm{L}$ sodium bicarbonate and 10\% Fetal Bovine Serum (FBS) (Sigma). Cells were cultured in a humidified condition with $5 \% \mathrm{CO}_{2}$.

\section{Preparation of plant extract:}

The different parts of the Eupatorium triplinerve plant was collected from, The Nilgiris, Tamil Nadu, India. The collected plant parts were then shade dried and made as powdered material. It was then extracted with the methanol using the maceration technique. The macerated extract was then clarified, filtered and stored at refrigeration condition until use.

\section{Qualitative phytochemical tests}

The qualitative analysis is very important to identify the phytochemical constituents present in the different parts of medicinal plant Eupatorium triplinerve. The medicinal value is purely depending upon the bioactive compounds present in it. The extracted plant samples were then subjected to qualitative screening to confirm the presence of phytochemicals like saponins, tannins, steroids, starch, carbohydrates, proteins, amino acids, alkaloids, phenols, flavonoids and glycosides following the standard protocols [7].

\section{Trypan blue exclusion test}

The cell viability was determined by trypan blue dye exclusion dye method. The cancer cells and the normal cells were seeded at a density of $1 \times 10^{6}$ cells/well with different concentration of extracts and incubated at $37^{\circ} \mathrm{C}$ in the presence of $5 \% \mathrm{CO}_{2}$. After $72 \mathrm{hr}, 20 \mu \mathrm{l}$ of medium and equal volume of $0.2 \%$ trypan blue were mixed, viable and dead cells were counted by Neubauer haemocytometer [8].

Cell viability $(\%)=$ Number of live cells/Number of total cells $\mathrm{x} 100$

\section{MTT assay}

Cells were seeded in 96-well tissue culture plate at a concentration of $1 \times 10^{6}$ cells/well. Stock solutions of extracts $(1 \mathrm{mg} / \mathrm{ml})$ were prepared in DMSO and diluted to the required concentrations $(1000,500,250,125$ and $62.5 \mu \mathrm{g} / \mathrm{ml})$ using the cell culture medium. Appropriate concentration was added to the cell cultures and incubated for $72 \mathrm{hrs}$ at $37^{\circ} \mathrm{C}$. Incubated cells was then subjected to MTT (3- $(4,5-$ Dimethylthiazol-2-yl)-2), 5-diphenyltetrazolium bromide, and concentration determined by colorimetric assay. The tetrazolium is used to determine cell viability in assays of cell proliferation and cytotoxicity. MTT is reduced in metabolically active cells to yield an insoluble purple formazon product. Assay plates were read using an ELISA reader at $520 \mathrm{~nm}$. The cytotoxicity data was standardized by determining absorbance and calculating the correspondent extract concentrations. Data generated were used to plot a dose-response curve of which the concentration of extract required to kill $50 \%$ of cell population $\left(\mathrm{IC}_{50} / \mathrm{CTC}_{50}\right)$ was determined [9].

$\%$ Growth Inhibition $=(100-[(\mathrm{OD}$ value of control/OD values of test)] x 100)

\section{RESULTS AND DISCUSSION}

The plant extract was subjected to various phytochemicals analysis tests and were found to contain alkaloids, carbohydrates, amino acids, proteins, tannins, phenolics, saponins, steroids and flavonoids (Table 1).

Table 1: Phytochemical analysis of Eupatorium triplinerve methanol extract

\begin{tabular}{|r|l|c|}
\hline S. No & \multicolumn{1}{|c|}{ Name of the test } & Methanol extract \\
1. & Alkaloids & + \\
\hline 2. & Carbohydrates & + \\
3. & Glycosides & - \\
\hline 4. & Proteins & + \\
\hline 5. & Amino acids & + \\
\hline 6. & Tannins & + \\
\hline 7. & Phenolics & + \\
\hline 8. & Saponins & + \\
\hline 9. & lavonoids & + \\
\hline 10. & Steroids & + \\
\hline
\end{tabular}

$$
+=\text { Presence, }-=\text { Absence }
$$

Medicinal plants are used for discovering and screening of the phytochemical constituents which are helpful for the discovery of new drugs. This present study has revealed the presence of phytochemicals and can be considered as active chemical constituents. The obtained results are comparable with the previous reports such as flavonoids are found in many plants such as Punica granatum, Psidium gujauva, Morus alba, Ficus palmate, Fagonia cretica and Acacia nilotica [10]. Epidemiologic studies recommend that coronary heart disease is opposed by dietary flavonoids and plants having alkaloids are used in medicines for reducing headache and fever. The presence of phenolics confers for the antibacterial activity of the extract [11]. The antidiuretic, anti-inflammatory, antianalgesic, anticancer, antiviral, antimalarial, antibacterial and antifungal activities of the medicinal plants are due to the presence of the secondary metabolites [12]. 
Table 2: Determination of mitochondrial synthesis by MTT assay in A-549 lines and Vero cells

\begin{tabular}{|c|c|c|c|}
\hline Sample & $\begin{array}{c}\text { Concentration } \\
(\boldsymbol{\mu g} / \mathbf{m l})\end{array}$ & $\begin{array}{c}\mathbf{C T C}_{\mathbf{5 0}} \\
\mathbf{A - 5 4 9} \\
\text { cells }\end{array}$ & $\begin{array}{c}\mathbf{C T C}_{\mathbf{5 0}} \\
\text { Vero } \\
\text { cells }\end{array}$ \\
\hline Eupatorium & 1000 & & \\
triplinerve & 500 & 450 & 110 \\
methanol extract & 250 & $\mu \mathrm{g} / \mathrm{ml}$ & $\mu \mathrm{g} / \mathrm{ml}$ \\
& 125 & & \\
\hline
\end{tabular}

The cells were examined for its percentage viability by Trypan blue dye exclusion method and cell viability was found to be $95-98 \%$ for both A-549 and Vero cell lines. The cells below $95 \%$ viability are not considered for cytotoxic activity.

The cytotoxicity study was carried out for the crude methanol extract of the plant. Cytotoxic activities of all the test compound was expressed as percentage growth inhibition in MTT assay. The $\mathrm{CTC}_{50}$ value for methanol extract was found to be $450 \mu \mathrm{g} / \mathrm{ml}$ for A-549 and $110 \mu \mathrm{g} / \mathrm{ml}$ for Vero cell line respectively (Table 2 ).

The study reveals that the E. triplinerve has potential in inhibiting lung cancer cells. In normal cells at higher concentration the viability percentage was moderate and decrease in concentration has increased viability as the toxic level in crude is more at higher concentration. This implies increase in concentration has started inhibiting the normal cells. Concentration below $500 \mu \mathrm{g} / \mathrm{ml}$ has showed drastic decrease in two-fold in dead cells. The ranges between 250 $500 \mu \mathrm{g} / \mathrm{ml}$ have clearly determined the $\mathrm{CTC}_{50}$ value as $450 \mu \mathrm{g} / \mathrm{ml}$ for cancer cells (Fig 1 and 2) and $110 \mu \mathrm{g} / \mathrm{ml}$ for normal cells (Fig 3and 4).

The inevitability of finding the plants that replaces chemotherapy and cytotoxic towards the complicated disease like cancer is more essential [13]. Use of in vitro assays for the screening of potential anti cancer agent has been a common practice almost since the beginning of cancer chemotherapy. The gradual increase of using the active components of natural resources as the cytotoxic agent, plants are transfigured as the popular anticancer sources [14].

\section{CONCLUSION}

A crude extract is an extremely complicated mixture of several phyto compounds that possess pharmacological activities. The present study demonstrated the presence of phytochemicals such as alkaloids, carbohydrates, amino acids, proteins, tannins, phenol, saponins, steroids and flavonoids. The result obtained was comparably promising and this crude extract showed moderate activity against lung cancer cells and it was less toxic to normal cell. Future investigations are required to identify, isolate and purify the lead compound that could be used as a potent therapeutic tool against lung cancer.

\section{ACKNOWLEDGEMENT}

The authors are thankful to the authorities of CMS college of Science and Commerce for the facilities.

\section{Figures}

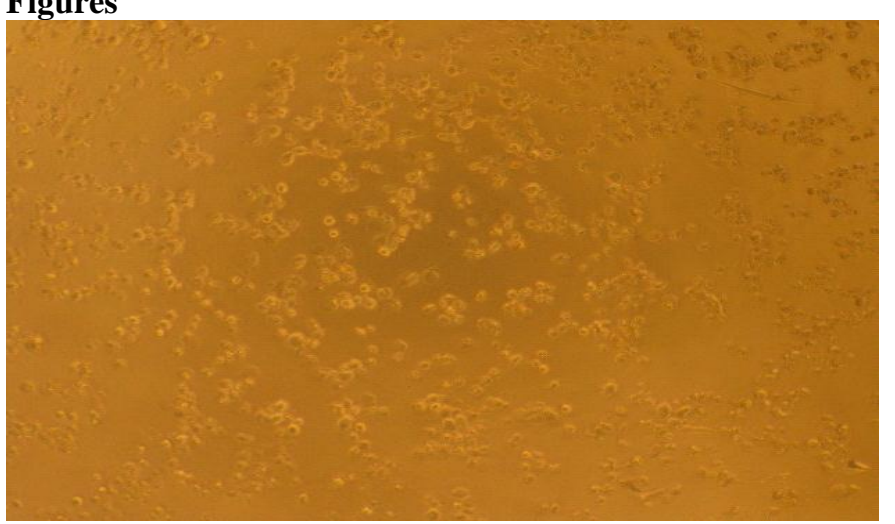

Fig.1 The cytotoxic effect of Eupatorium triplinerve methanol extract to A 549 cells

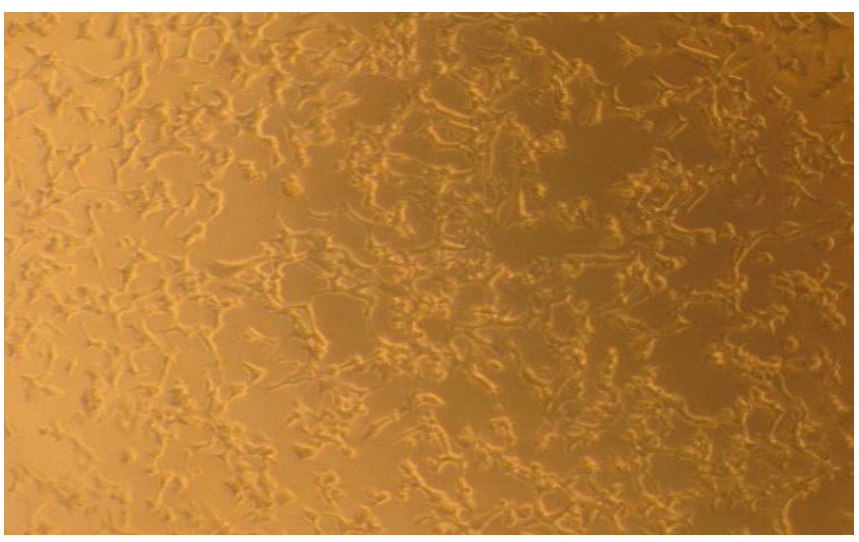

Fig.2 Control A 549 cells

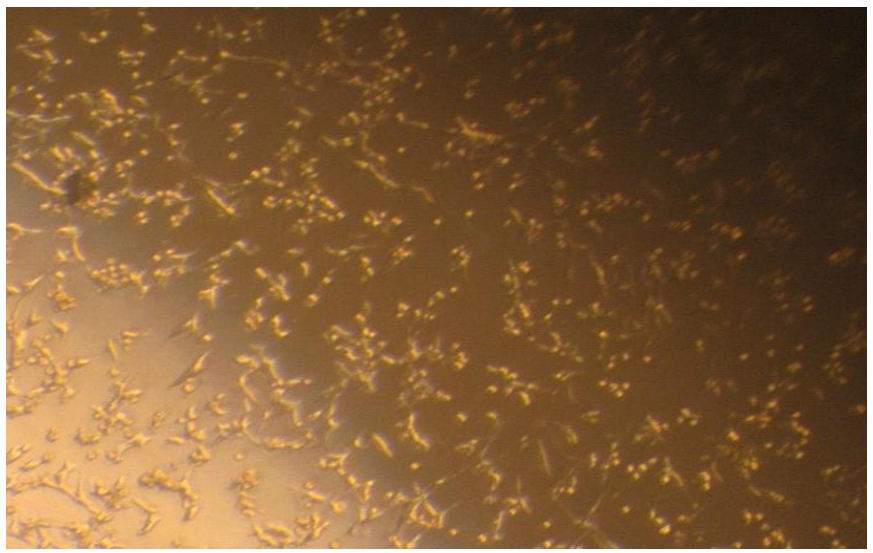

Fig. 3 Less cytotoxic effect of Eupatorium triplinerve methanol extract to Vero cells 


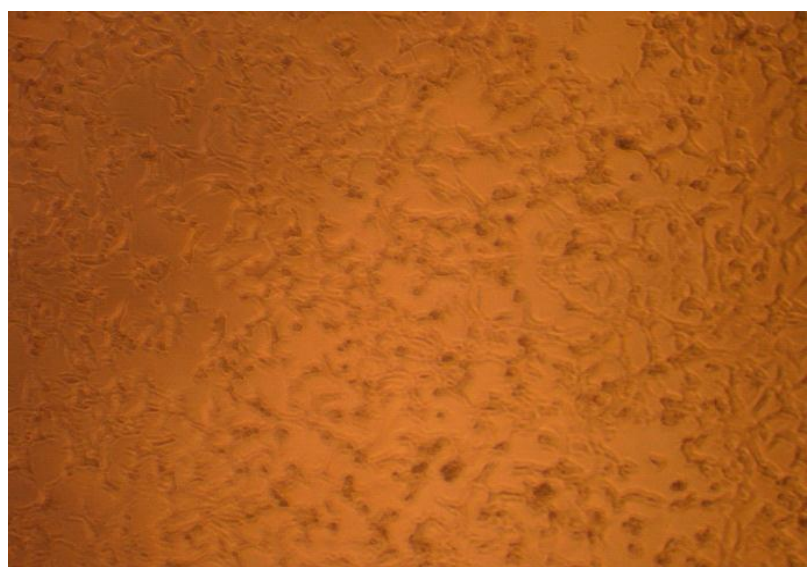

Fig. 4 Control cells of Vero

\section{REFERENCES}

[1]. S.K. Pal and B. Mittal B, "Fight against cancer in countries with limited resources: the post-genomic era scenario", Asian Pacific Journal of Cancer Prevention, Vol. 5, Issue 3, pp. 328-33, 2004.

[2]. S. Alam, P. Satpathy, A. Thosar, "Plants and its parts as a source of Anti-Cancer Compounds: a Review", International Research Journal of Pharmacy. Vol.5, Issue 4, pp. 244-249, 2014.

[3]. W. Kooti, K. Servatyari, M. Behzadifar, "Effective Medicinal Plant in Cancer Treatment, Part 2: Review Study", Journal of Evidence-Based Complement Alternative Medicine, Vol. 22, Issue 4, pp.982-995, 2017.

[4]. E. Mansouri, W. Kooti, M. Bazvand, "The effect of hydroalcoholic extract of Foeniculum vulgare Mill on leukocytes and hematological tests in male rats". Jundishapur Journal of Natural Pharmaceutical Products. Vol.10, pp. e18396, 2015.
[5]. W. Kooti, M. Ghasemiboroon, M. Asadi-Samani, "The effects of hydro-alcoholic extract of celery on lipid profile of rats fed a high fat diet", Advances in Environmental Biology. Vol.8, pp.325330, 2014.

[6]. W. Kooti, Z. Hasanzadeh-Noohi, N. Sharafi-Ahvazi, M. AsadiSamani, D. Ashtary-Larky, "Phytochemistry, pharmacology and therapeutic uses of black seed - Nigella sativa", Chinese Journal of Natural Medicine. Vol.14, pp.732-745, 2016.

[7]. Anees Ahmed Siddique and Mohammed Ali. Practical Pharmaceutical Chemistry, CSB publishiers, India, pp.126-132, 2008.

[8]. W. Strober, 'Tryphan blue exclusion test of cell viability", Current Protocol of Immunology, John Wiley \& Sons publishers, U.K, pp. A3.B.1- A3.B.2D, 1997

[9]. A. Scudiero, R.H. Shoemaker, K. D. Paul, "Evaluation of soluble Tetrazolium Formazan assay for cell growth and drug sensitivity in cultures using human and other tumor cell lines", Cancer Research. Vol. 48, pp. 4827- 4833, 1998.

[10].P.G. Pietta, "Flavonoids as antioxidants", Journal of Natural Products. Vol.63, pp. 1035-1042, 2000.

[11]. S. Yogisha and K. A. Raveesha, "In-vitro antibacterial effect of selected medicinal plant extracts", Journal of Natural Products, Vol. 2, pp.64-69, 2009.

[12]. M.S. Uma Maheswari, R. Rajendran, "Comparative Evaluation of Qualitative and Quantitative Phytochemical Analysis of South Indian Bioactive Medicinal Plant Tribulus terrestris", International Journal of Scientific Research in Biological Sciences, Vol.5, Issue.6, pp.144-149, 2018.

[13]. K. F. Sigaroodi, M. Jeddi-Tehrani, M. Ahvazi M, "Cytotoxicity evaluation of Taverniera spartea on human cancer cell lines", Journal of Medicinal Plants. Vol.2. pp.114-128, 2014.

[14]. J. Guna Priya, K. Geetha Lakshmi, Niharika Sharma, D. Rajani, "A Comparative Study of Antioxidants and Antimicrobial activity in Vegetables, Leafy Vegetables and Spices”, International Journal of Scientific Research in Biological Sciences, Vol.06, Issue.01, pp.80-85, 2019. 